\title{
Chemical Nature of Toxohormone (Nakahara)
}

\author{
Eighth Report. Toxohormone AP $\mathrm{I}_{1}$ and $\mathrm{I}^{\prime}$ from Cancerous and \\ Noncancerous Ascitic Fluids*
}

By

\section{Hajime Masamune, Sigetosi Kamiyama, Sin-iti Abe,

(正宗 一) (加美山茂利) (阿部 辰一)

Shoichi Abe, Mituo Haga and Hirosi Kaketa

(阿部 正一) (势賀光男) (掛田 博)

From the Medico-chemical Institute, Tohoku University, Sendai

(Received for publication, January 15, 1959)

Formerly we $^{1)}$ mentioned that two toxohormones, one KIK-active and the other KIK-inactive, are secreted in urine of not only cancer patients but also normals. And, from gastric cancer as well as non-cancered gastric mucosa were isolated two different toxohormones ${ }^{2}$, although both are group active mucopolysaccharides. Thus it might be said that generally one secretion or one tissue contains more than one kind of toxohormone. Regarding the cancerous ascitic fluid, we have detected so far three toxohormones in it, one of which is AP I ${ }^{3)}$ a globulin possessing simultaneously KIK potency, a second the KIK-active glucidamin reported by Sugimoto ${ }^{4}$ ) and a third a globulin closely resembling AP I but KIK-inactive.

The present account deals with the last toxohormone from cancerous ascitic fluids with original seat in stomach (AP II $)_{1}$ as well as a corresponding protein from ascitic fluids due to liver-cirrhosis as a representative kind of noncancerous ascitic fluid (AP II').

\section{EXPERIMENTAI.}

Preparation Procedure of the Toxohormones

For each of the two kinds of toxohormone, one example of preparation runs will be described.

$A P I I_{1}$, a toxohormone-active globulin other than AP I from cancerous ascitic fluids with original seat in stomach

First stage. $4.3 \mathrm{l}$. of combined cancerous ascitic fluids (light yellow, transparent ; $\mathrm{pH} 8.2 ; \mathrm{d} 1.015)$ from a stomach cancer patient was distilled in vacuo to about $800 \mathrm{cc}$., and the condensate was dialyzed against running water for 3 days, transferred to the middle compartment of a Pauli apparatus without antecedently separating off some precipitate, that had occurred

* 14th report of Masamune and co-workers' "On Proteins and Amino Acids". 
during dialysis, and electrodialyzed until no more flow of electricity. The precipitate increased enormously thereby. The whole deposit was centrifuged, washed with ethanol and ether in succession and dried in vacuo over anhydrous calcium chloride. $42 \mathrm{~g}$. of a gray powder (ascitic globulins $=\mathrm{AG})$ was obtained.

Second stage. $42 \mathrm{~g}$. of AG was pulverized, suspended in $600 \mathrm{cc}$. of distilled water, and after addition of $10 \% \mathrm{NaOH}$ to $\mathrm{pH} 9.0$, stood in a refrigerator $\left(0-3^{\circ} \mathrm{C}\right)$ additionally adding the $\mathrm{NaOH}$ solution from time to time to maintain the $\mathrm{pH}$ value at 8.5-9.0. After 5 days, the mixture was supplemented with water to $800 \mathrm{cc}$. and centrifuged in a refrigerated centrifuge $\left(0^{\circ} \mathrm{G}\right)$, and the opalescent supernatant $(165 \mathrm{cc}$.) was neutralized with $1 N \mathrm{HCl}$ and freed from some precipitate that had occurred thereby. $29.7 \mathrm{~g}$. (18 g. per $100 \mathrm{cc}$. of the solution) of sodium chloride was added to the centrifuged supernatant (163 cc.), and this mixture was placed in the refrigerator for one day with occasional agitation and acidified to $\mathrm{pH} 4.2$ with $1 N \mathrm{HCl}$. The abundant white precipitate was centrifuged off at $0^{\circ} \mathrm{C}$ and washed with two $60 \mathrm{cc}$. portions of $18 \% \mathrm{NaCl}$ of $\mathrm{pH} 4.2$. It was next suspended in $200 \mathrm{cc}$. of distilled water, adjusted to $\mathrm{pH} 8.5$ with $5 \% \mathrm{NaOH}$ and freed from sodium chloride by 3 days' dialysis against running water. The solution which had changed intensively cloudy was

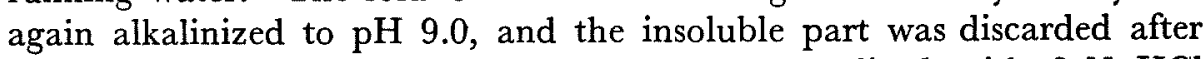
centrifugation. The supernatant here was neutralized with $2 \mathrm{~N} \mathrm{HCl}$ exactly to $\mathrm{pH} 7.0$, the small precipitate was eliminated, and after making up to $165 \mathrm{cc}$., the solution was subjected to alcoholic fractionation (next stage).

Third stage. $55 \mathrm{cc}$. of the neutral solution above was diluted to $100 \mathrm{cc}$. and chilled on ice, and abs. ethanol was added under vigorous agitation in such portions as each increased the ethanol concentration by $10 \%(\mathrm{v} / \mathrm{v})$, centrifuging off every deposit in the refrigerated centrifuge after 2-3 hours. The centrifugates were separately washed with ethanol and ether and dried as above, with the yields of fractions :

$\begin{array}{lccccccc}\text { Fraction No. } & \text { I } & \text { II } & \text { III } & \text { IV } & \text { V } & \text { VI } & \text { VII } \\ \begin{array}{c}\text { Ethanol concn. } \\ (\%(\mathrm{v} / \mathrm{v}))\end{array} & 0-10 & 10-20 & 20-30 & 30-40 & 40-50 & 50-60 & 60-70 \\ \text { Yield (mg.) } & 30 & 13 & 10 & 45 & 135 & 680 & 120\end{array}$

The balance of the solution at the end of the second stage was also treated in a similar manner, and the fractions which precipitated at 40 $50 \%$ ethanol and those at $50-60 \%$ ethanol were united together. The total amount given was $2.4 \mathrm{~g}$.

Fourth stage. As AG was in the second stage, $2.4 \mathrm{~g}$. of the product was taken up in $200 \mathrm{cc}$. of water by means of alkali, and the part that was insoluble at $\mathrm{pH} 9.0$ and that precipitated on shifting the hydrogen ion 
concentration to $\mathrm{pH} 7.0$ were eliminated. The light opalescent centrifuged supernatant (neutral) was made up to $240 \mathrm{cc}$. with water and fractionated by addition of $6.6 \mathrm{~g}$. portions of solid ammonium sulfate, each of which increased the concentration of this salt by $0.2 \mathrm{M}$, in the manner alcoholic fractionation was carried out above. The fractions precipitated here were separately dissolved in $70-150 \mathrm{cc}$. of water and dialyzed against running water for 3-4 days to remove ammonium sulfate, employing toluene as a preservative. Then, the solutions were distilled under reduced pressure to syrupy consistency, dehydrated with excessive ethanol, washed with ethanol and ether and dried as above with yields:

\begin{tabular}{|c|c|c|c|c|c|c|c|c|}
\hline Fraction No. & I, II, III & IV & $\mathrm{V}$ & VI & VII & VIII & IX & \\
\hline $\begin{array}{l}\text { Molarity of } \\
\text { ammonium } \\
\text { sulfate }(M)\end{array}$ & $\begin{array}{c}0-0.4 \\
0.4-0.6, \\
0.6-0.8\end{array}$ & $0.8-1.0$ & $1.0-1.2$ & $1.2-1.4$ & $1.4-1.6$ & $1.6-1.8$ & $1.8-2.0$ & $2.0 \ldots 3.0$ \\
\hline Yield (mg.) & 0 & 64 & 1080 & 373 & 297 & 85 & 75 & 157 \\
\hline
\end{tabular}

Frs. V-VII were dissolved together in $130 \mathrm{cc}$. of water in the same manner as AG was in the second stage (Here almost no precipitate occurred when the solution of $\mathrm{pH} 9.0$ was neutralized), and the neutral solution was made up to $160 \mathrm{cc}$. and fractioned by successive addition of $4.22 \mathrm{~g}$. portions of ammonium sulfate as above. The deposits were freed from the salt, condensed, precipitated, washed and dried also as above. The yields here amounted as follows :

$\begin{array}{lccccc}\text { Fraction No. } & \text { I } & \text { II } & \text { III } & \text { IV } & \text { V } \\ \begin{array}{l}\text { Molarity of } \\ \text { ammonium sul- } \\ \text { fate }(M)\end{array} & 0.6-0.8 & 0.8-1.0 & 1.0-1.2 & 1.2-1.4 & 1.4-1.6 \\ \text { Yield }(\mathrm{mg} .) & 37 & 141 & 755 & 424 & 117\end{array}$

Fifth stage. $1.1 \mathrm{~g}$. of united Fr. III and IV was suspended in $100 \mathrm{cc}$. of water, dissolved by the aid of $\mathrm{NaOH}$ also as $\mathrm{AG}$ was in the second stage and electrodialyzed, and the deposit thereby was centrifuged off, washed with water (about $60 \mathrm{cc}$.), and after again dissolving in $40 \mathrm{cc}$. of water by

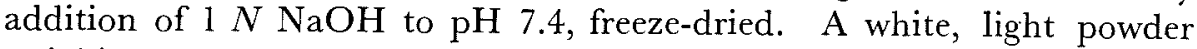
weighing $0.95 \mathrm{~g}$. was given $-\mathbf{A P} \mathbf{I}_{1}$.

AP II', a corresponding protein fraction of ascitic fuids from liver cirrhosis patients as a representative kind of non-cancerous ascitic fluid

Starting with $1.6 l$. of an ascitic fluid (yellowish, transparent ; pH 8.2 ; d 1.015) from a liver-cirrhosis patient, $0.62 \mathrm{~g}$. of a white, light powder corresponding to AP $\mathrm{II}_{\mathbf{I}}-\mathbf{A P} \mathbf{I I}^{\prime}$-was obtained in a manner similar to above without setting aside the intermediate products partially. The main part of the toxohormone here fell on the corresponding fractions to those above in fractionation with ethanol as well as in fractionations with ammonium sulfate. 


\section{Properties of the Preparatoins}

1) Homogeneity. $\mathrm{AP} \mathrm{II}_{1}$, and $\mathrm{II}^{\prime}$ gave each a single, symmetrical boundary after electrophoresis in either of an alkaline $(\mathrm{pH}$ 8.6) and an acid ( $\mathrm{pH} 2.0$ ) buffer. Their mobilities in the alkaline buffer were not the same. The examination was made in a Tiselius apparatus of HTD-1 type Hitachi. See Fig. 1.
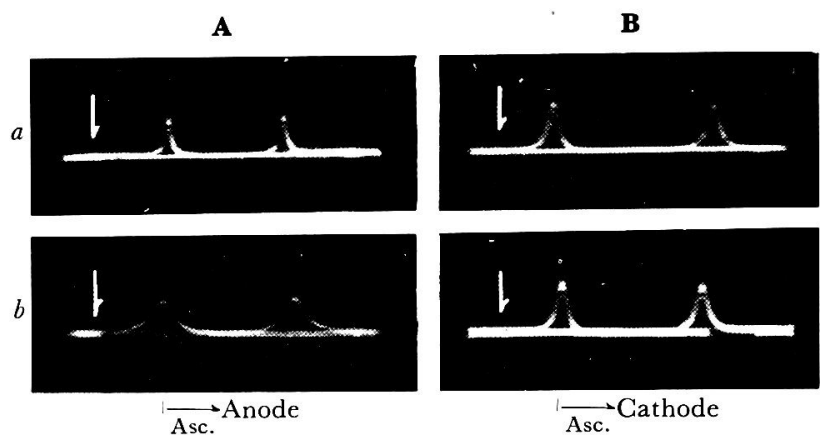

Fig. 1. Electrophoresis patterns $(\times 2 / 3)$ of $1 \%$ solutions in a veronal- $\mathrm{HCl}$ buffer of $\mathrm{pH} 8.6$ and $\mathrm{I} 0.2(\mathbf{A})$ and a glycine- $\mathrm{HCl}$ buffer of $\mathrm{pH} 2.0$ and $\mathrm{I} 0.2$ (B) of AP $\mathrm{II}_{1}(a)$ and AP II' $(b)$; current $5 \mathrm{~mA}$; temperature $10^{\circ} \mathrm{C}$; exposure 120 minutes after starting current. Mobility :

$$
\begin{array}{rrl}
\text { AP II } & \text { pH } 8.6 \frac{(-1.15) \times 0.01043 \times 0.18}{120 \times 60 \times 0.005}=-6.00 \times 10^{-5} \mathrm{~cm}^{2} / \mathrm{volt} / \mathrm{sec} \\
& \text { pH } 2.0 \frac{(-0.80) \times 0.01544 \times 0.18}{120 \times 60 \times 0.005}=-6.18 \times 10^{-5} \quad, \\
\text { AP II' pH } 8.6 \frac{(-1.08) \times 0.01043 \times 0.18}{120 \times 60 \times 0.005}=-5.63 \times 10^{-5} \quad, \\
\text { pH } 2.0 \frac{(-0.92) \times 0.01544 \times 0.18}{120 \times 60 \times 0.005}=-7.10 \times 10^{-5} \quad,
\end{array}
$$

The homogeneity of the preparations was further ascertained by column chromatography :- A $1.1 \times 20 \mathrm{~cm}$. column of a strong anion exchanger Dowex $1 \times 2(200-400$ mesh) was equilibrated with $0.025 \mathrm{M}$ borax- $\mathrm{HCl}$ buffer of $\mathrm{pH}$ 8.5, and 2 or $1 \mathrm{cc}$. of the same buffer containing $20 \mathrm{mg}$. of AP $\mathrm{II}_{1}$ or $10 \mathrm{mg}$. of $\mathrm{AP} \mathrm{II}^{\prime}$ respectively was added, and washed with also the same buffer at a flow rate of 40 drops per hour. The eluate was collected in fractions of 20 drops (about $2 \mathrm{cc}$.) and analyzed by a biuret reaction (Gornall et al..$^{5}$ ) and measurement of ultraviolet absorption at $280 \mathrm{~m} \mu$. The results are diagrammed in Fig. 2, showing a single symmetrical peak of concentration in a definite range of fractions for either of the substances. Namely, the preparations again proved homogeneous.

2) Toxohormone activity. It was assayed by our usual method ${ }^{3)}$. As shown in Table $\mathrm{I}$, the minimum toxohormone active dosis of $\mathrm{AP} \mathrm{II}_{1}$ and II' were found about 2 and $4 \mathrm{mg}$. respectively. 


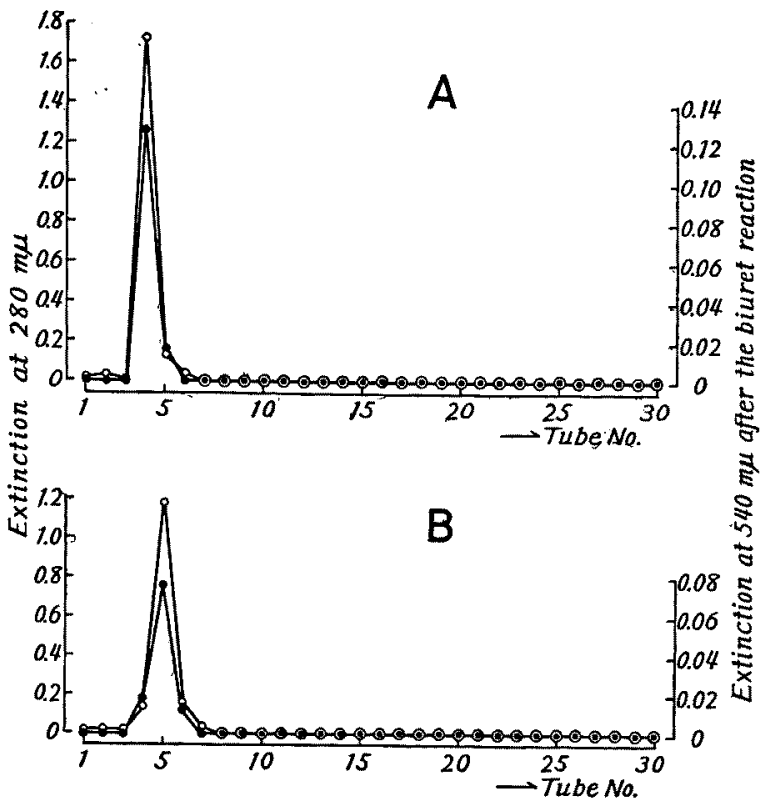

Fig. 2. Column chromatograms of $20 \mathrm{mg}$. of $\mathrm{AP} \mathrm{II}_{\mathbf{1}}(\mathbf{A})$ and $10 \mathrm{mg}$. of AP II' $(\mathbf{B})$ developed by the aid of a Dowex $1 \times 2$ column. -O-O-Extinctions at $280 \mathrm{~m} \mu$. - Extinctions at $540 \mathrm{~m} \mu$ after the biuret reaction.

\section{TABLE I-A}

Liver-catalase Depression in vivo

The average $\mathrm{O}_{2}$ volume evolved for each dosis in each test-set is expressed in per cent of the corresponding $\mathrm{O}_{2}$ volume in the blank control.

\begin{tabular}{|c|c|c|c|c|c|}
\hline \multirow{2}{*}{ Assay No. } & \multirow{2}{*}{$\begin{array}{l}\text { Number of } \\
\text { mice used }\end{array}$} & \multicolumn{4}{|c|}{ Amount of substance injected (mg.) } \\
\hline & & 5 & 3 & 1 & 0.5 \\
\hline \multicolumn{6}{|c|}{ By AP $~_{1}$ : } \\
\hline $\begin{array}{l}1 \\
2 \\
3 \\
4 \\
5 \\
6 \\
7\end{array}$ & $\begin{array}{r}12 \\
9 \\
9 \\
9 \\
6 \\
6 \\
9\end{array}$ & & $\begin{array}{l}62.8 \\
58.8 \\
65.3 \\
72.7\end{array}$ & $\begin{array}{l}76.0 \\
80.3 \\
76.6 \\
79.1 \\
83.5\end{array}$ & $\begin{array}{l}91.4 \\
70.9 \\
82.2 \\
91.1\end{array}$ \\
\hline Average & & & 64.9 & 79.1 & 83.9 \\
\hline \multicolumn{6}{|c|}{ By AP I' : } \\
\hline $\begin{array}{r}8 \\
9 \\
10 \\
11 \\
12\end{array}$ & $\begin{array}{r}9 \\
12 \\
12 \\
9 \\
9\end{array}$ & $\begin{array}{l}74.4 \\
63.4 \\
64.8 \\
68.5 \\
71.4\end{array}$ & $\begin{array}{l}77.9 \\
70.3 \\
82.7 \\
73.2\end{array}$ & $\begin{array}{l}75.2 \\
85.3 \\
86.1\end{array}$ & \\
\hline Average & & 68.5 & 76.0 & 82.2 & \\
\hline
\end{tabular}


TABLE I-B

Effect in vivo on Kidney- and Blood-catalase

\begin{tabular}{c|c|c|c}
\hline Assay No. & Kidney & Blood & Liver \\
\hline Effect of AP $\mathbf{I}_{1}$ : & & \\
\hline \multicolumn{2}{|c|}{ Oxygen evolved (cc.) in blank experiment } \\
\hline 201 & 5.2 & 1.6 & 15.8 \\
202 & 5.3 & 1.9 & 15.5 \\
203 & 3.5 & 2.2 & 12.3 \\
\hline Average & 4.3 & 1.9 & 14.5 \\
\hline & Oxygen evolved (cc.) in main experiment & \\
\hline 204 & 4.0 & 1.9 & 10.9 \\
205 & 4.9 & 1.7 & 10.6 \\
206 & 5.1 & 2.0 & 10.2 \\
\hline $\begin{array}{c}\text { Average } \\
\text { (\% of control value) }\end{array}$ & 4.7 & 1.9 & 10.6 \\
\hline
\end{tabular}

Effect of AP $\mathbf{I}^{\prime}$ :

\begin{tabular}{c|c|c|c}
\hline \multicolumn{3}{|c}{ Oxygen evolied (cc.) in blank experiment } \\
\hline 207 & 5.1 & 2.4 & 13.5 \\
208 & 5.8 & 2.0 & 13.3 \\
209 & 4.4 & 2.4 & 14.6 \\
\hline Average & 5.1 & 2.3 & 13.8 \\
\hline & Oxygen evolved (cc.) in main experiment & \\
\hline 210 & 4.5 & 2.3 & 11.2 \\
211 & 5.3 & 2.2 & 7.9 \\
212 & 5.7 & 2.5 & 10.7 \\
\hline $\begin{array}{c}\text { Average } \\
\text { of control value) }\end{array}$ & $(102)$ & 2.3 & 9.9 \\
& & $(100)$ & $(72)$ \\
\hline
\end{tabular}

3) KIK activity. The method Masamune and Kawasaki described ${ }^{6}$ was applied. The result is illustrated in Table II. The substances are regarded as KIK-inactive, because neither of them induced anemia in rabbits even when injected intravenously in dosage of $1.5 \mathrm{mg}$. per $\mathrm{kg}$. body weight.

4) Paper chromatography of the sugars and amino acids constituting the preparations. a) Sugars. $10.6 \mathrm{mg}$. of AP $\mathrm{II}_{1}$ was heated with $1 \mathrm{cc}$. of $1 \mathrm{~N}$ sulfuric acid in a sealed tube at $100^{\circ} \mathrm{C}$ for 5 hours. About $3.5 \mathrm{cc}$. of the satd. baryta was added to the hydrolysate until a $\mathrm{pH}$ value of 4.0 , and the 
TABLE I-C

Effect in vitro on Liver-catalase

\begin{tabular}{|c|c|c|c|}
\hline \multirow[b]{2}{*}{ Assay No. } & \multicolumn{3}{|c|}{ Liver-catalase activity (oxygen evolved in cc.) } \\
\hline & $\begin{array}{c}\text { Control I } \\
\text { (No incubation) }\end{array}$ & $\begin{array}{l}\text { Control II } \\
\text { (Incubated without } \\
\text { toxohormone) }\end{array}$ & $\begin{array}{l}\text { Main } \\
\text { (Incubated with } \\
\text { toxohormone) }\end{array}$ \\
\hline \multicolumn{4}{|c|}{ Effect of $A P \Pi_{1}(3 \mathrm{mg}$ ) : } \\
\hline 301 & 13.8 & 11.8 & 12.0 \\
\hline 302 & 12.5 & 9.0 & 8.9 \\
\hline 303 & 16.5 & 10.5 & 10.3 \\
\hline Average & 14.3 & 10.4 & (99\% of Control II value) \\
\hline \multicolumn{4}{|c|}{ Effect of AP $\mathbf{I}^{\prime}(5 \mathrm{mg}$ ) : } \\
\hline 304 & 16.5 & 11.3 & 10.8 \\
\hline 305 & 15.2 & 11.5 & 11.8 \\
\hline 306 & 12.0 & 8.4 & 9.2 \\
\hline Average & 14.6 & 10.4 & $\begin{array}{c}10.6 \\
\text { (102\% of Control II value) }\end{array}$ \\
\hline
\end{tabular}

TABLE II

Anemia-inducing Potency of $\mathrm{AP} \mathrm{II}_{1}$ and $\mathrm{II}^{\prime}$

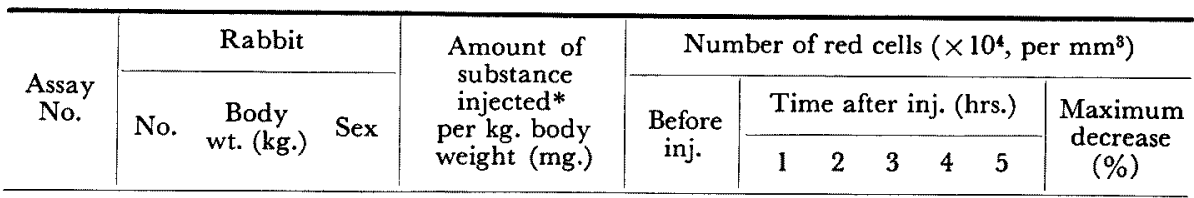

The potency of $\mathbf{A P} \mathbf{I}_{1}$ :

\begin{tabular}{|c|c|c|c|c|c|c|c|}
\hline 1 & 35 & 2.0 & 우 & 1.5 & 551 & $\begin{array}{lllll}568 & 559 & 601 & 540 & 534\end{array}$ & 4 \\
\hline 2 & 36 & 2.2 & $\delta$ & 1.5 & 533 & $\begin{array}{lllll}521 & 544 & 479 & 496 & 492\end{array}$ & 8 \\
\hline \multicolumn{8}{|c|}{ The potency of AP II': } \\
\hline 3 & 35 & 2.0 & 오 & 1.5 & 590 & $\begin{array}{lllll}588 & 579589 & 587 & 569\end{array}$ & 4 \\
\hline 4 & 36 & 2.2 & $\hat{\delta}$ & 1.5 & 750 & 790739757777755 & 1 \\
\hline
\end{tabular}

* Intravenously.

precipitate was centrifuged off and discarded after washing with warm water. The supernatant and washing were evaporated to about $1 \mathrm{cc}$. by standing in vacuo over anhydrous calcium chloride, and the deposit occurring thereby was filtered off and washed. The filtrate and washing here were distilled to dryness, and the still-residue was dissolved in $0.1 \mathrm{cc}$. of 

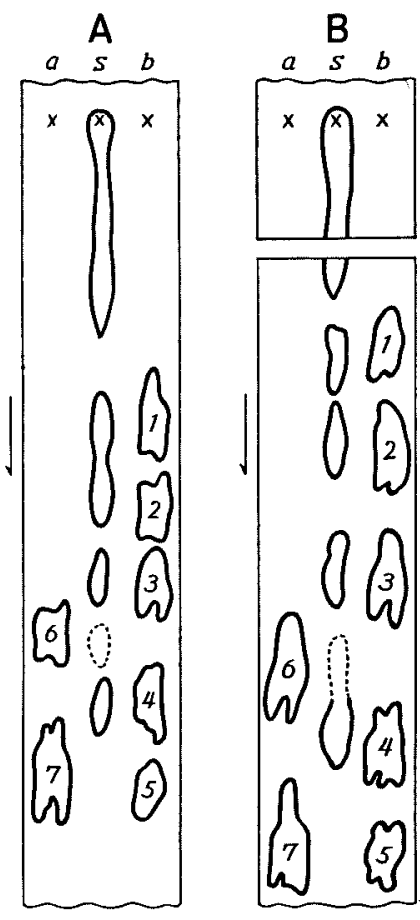

Fig. 3. Sugar paper chromatograms $(\times 2 / 5)$ of the hydrolysates of $\mathrm{AP} \mathrm{II}_{1}(\mathbf{A})$ and of AP II' (B) developed with solvent butanol-pyridinewater (5:3:2) ; slivers $60 \times 7 \mathrm{~cm}$., Toyo Roshi filter paper ; irrigation descending; temperature of test : AP $\mathrm{II}_{1} 25^{\circ} \pm 2^{\circ} \mathrm{C}, \mathrm{AP} \mathrm{II}^{\prime} 22^{\circ} \pm 1^{\circ} \mathrm{C}$; duration of test: AP $\mathrm{II}_{1} 20 \mathrm{hrs}$., AP II' $24 \mathrm{hrs}$. Reference runs effected with $1 \%$ solutions with respect to individual sugars. Indicator aniline hydrogen phthalate reagent of Partridge.

$a, b$ : reference. $s$ : main run. 1 galactosamine, 2 glucosamine, 3 galactose, 4 mannose, 5 L-fucose, 6 glucose, 7 xylose.

water and paper-chromatographed according to Masamune and Yosizawa $^{7)}$. As regards AP II', $18.2 \mathrm{mg}$. of it was hydrolyzed, and the stillresidue of the hydrolysate free from $\mathrm{H}_{2} \mathrm{SO}_{4}$ was dissolved in 0.1 cc. and chromatographed taking $0.04 \mathrm{cc}$. of the solution. See Fig. 3.

In either of the chromatograms, spots were shown at the positions corresponding to galactosamine, glucosamine, galactose and mannose. It is doubtful that the very faint spots at the positions corresponding to glucose are plausibly ascribed to this sugar.

b) Amino acids. $5.6 \mathrm{mg}$. of $\mathrm{AP} \mathrm{II}_{1}$ was sealed with $1 \mathrm{cc}$. of $6 \mathrm{~N}$ $\mathrm{HCl}$ in an ampoule and heated in a boiling water-bath for 24 hours. The hydrolysate was freed from the hydrochloric acid by repeated vacuum evaporations over solid caustic soda to dryness, adding water to every residue. The final evaporated residue was taken up in $0.18 \mathrm{cc}$. of water (The solution was not perfectly clear), and $0.03 \mathrm{cc}$. of the solution was chromatographed on a $30 \times 30 \mathrm{~cm}$. square of Toyo Roshi filter paper No. 50 . Of AP II', 6 mg. was hydrolyzed, and the still-residue of the hydrolysate freed from the free hydrochloric acid was dissolved in $0.24 \mathrm{cc}$. of water and chromatographed taking $0.04 \mathrm{cc}$. of the solution. Aspartic and glutamic acids, serine, glycine, threonine, alanine, tyrosine, phenylalanine, leucine and/or isoleucine, valine and/or methionine, proline, hexone bases and a 

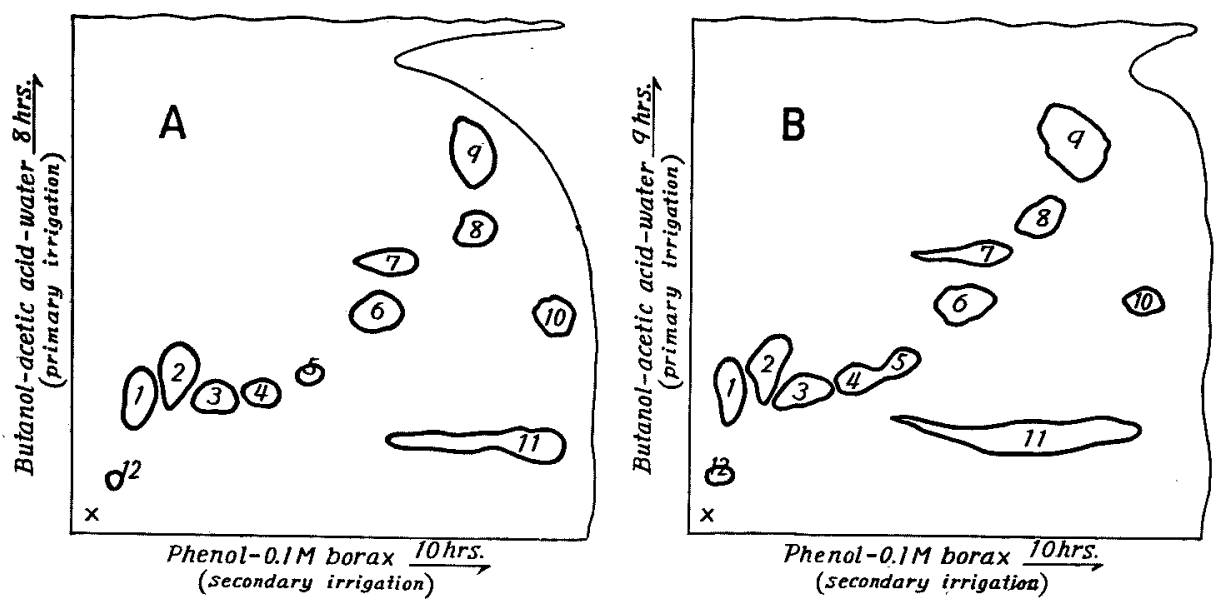

Fig. 4. Two-dimensional amino acid-paper chromatograms of the hydrolysates of AP II 1 (A) and of AP II' $(\mathbf{B})$, developed by employing solvent butanol. acetic acid-water $(4: 1: 2)$ for the primary irrigation and solvent phenol-0.1 $M$ borax $(10: 1)$ for the secondary irrigation. Paper square $30 \times 30 \mathrm{~cm}$., Toyo Roshi filter paper No. 50 . Temperature of test $20-25^{\circ} \mathrm{C}$. Spray reagent $0.2 \%$ ninhydrin in moist butanol.

1 aspartic acid, 2 glutamic acid, 3 serine, 4 glycine, 5 threonine, 6 alanine, 7 tyrosine, 8 valine and/or methionine, 9 phenylalanine, leucine and/or isoleucine, 10 proline, 11 hexone bases, 12 a probable peptide.

probable peptide were detected in AP $\mathrm{II}_{1}$ as well as in AP $\mathrm{II}^{\prime}$.

5) Test-tube tests. Both of the preparations were strongly biuret positive and weakly Molisch positive.

6) Quantitative analyses. The analytical figures are embodied in Table III. No quantitative discrepancies are discerned between AP II and II' regarding hexosamine and hexoses, because these components are too small in content to give reliably accurate values. With respect to the amino acids, serine is present less and the total sum of phenylalanine, leucine and isoleucine as expressed as leucine more in AP $\mathrm{II}_{1}$ than in AP II'.

7) Ultraviolet absorption. $0.5 \mathrm{mg} \%$ solutions in water were examined in a photoelectric spectrophotometer of EPU-2A type Hitachi. As shown in Fig. 5, ultraviolet absorption with maximum at $278 \mathrm{~m} \mu$ occurred in similar strengths by the two proteins.

8) Specific refraction. $1 \%$ solutions ( $\mathrm{pH} 8.0$ ) of the preparations were examined in an Abbe refractometer at $17.5^{\circ} \mathrm{C}$, giving resembling $[n]_{D}^{17,5}$ values :- 
TABLE III

Composition in per cent of $\mathrm{AP} \mathrm{II}_{1}$ and $\mathrm{AP} \mathrm{II}^{\prime}$

\begin{tabular}{|c|c|c|}
\hline Analysis & AP $\mathrm{II}_{1}$ & AP II' \\
\hline $\mathrm{N}^{*}$ & 14.4 & 14.4 \\
\hline Ash $\dagger$ & 0.8 & 1.6 \\
\hline \multicolumn{3}{|l|}{ Hexose $\ddagger$ (as galactose) } \\
\hline$\left(\mathrm{PHR}_{2}\right.$ & 2.1 & 1.4 \\
\hline$\left\{\mathrm{SMHR}_{2}\right.$ & 0.8 & 0.4 \\
\hline $\mathrm{HR}_{10}$ & 2.5 & 1.8 \\
\hline Hexosamine§ & 2.3 & 1.6 \\
\hline Pentose// & 0 & 0 \\
\hline MethylpentoseI & 0 & 0 \\
\hline \multicolumn{3}{|l|}{ Sialic acid** } \\
\hline$\{$ ER & 0 & 0 \\
\hline$\{\mathrm{DR}$ & 0 & 0 \\
\hline \multicolumn{3}{|l|}{ Amino acidst: } \\
\hline Aspartic acid & 14.8 & 16.2 \\
\hline Glutamic acid & 14.8 & 15.4 \\
\hline Serine & 11.6 & 14.3 \\
\hline Glycine & 6.4 & 7.5 \\
\hline Threonine & 5.8 & 6.4 \\
\hline Alanine & 6.2 & 5.8 \\
\hline Tyrosine & 3.2 & 2.9 \\
\hline Valine and methionine (as valine) & 7.0 & 6.4 \\
\hline Phenylalanine, leucine and isoleucine (as leucine) & 16.0 & 12.2 \\
\hline Proline & 6.6 & 6.0 \\
\hline Hexone bases (as lysine) & 7.5 & 6.8 \\
\hline
\end{tabular}

* Micro-Kjeldahl method. † Pregl method without use of $\mathrm{H}_{2} \mathrm{SO}_{4}$. $\ddagger$ Masamune and Sakamoto ${ }^{8}$. \& Masamune and Yosizawa ${ }^{9}$. $/ /$ Masamune and Sakamoto ${ }^{8)}$. TMasamune and Kawasaki ${ }^{10)}$. ** Werner and Odin (direct Ehrlich method and diphenylamine method) ${ }^{11}$. . †† A modification of Masamune and Hakomori method ${ }^{12)}$ (Solvent phenol-0.1 $M$ borax (10:1) was replaced for solvent phenol-0.1 $M$ borax (86:14)).

AP $\mathrm{II}_{1}$ :

$n=1.33513, \quad n_{0}=1.33324, \quad d^{17.5} / 4=1.0035, \quad d_{0}^{17.5} / 4=1.0003$

$[n]_{\mathrm{D}}^{1.5}=\frac{1.33513^{2}-1}{1.33513^{2}+2} \times \frac{1}{1.0035} \times \frac{100}{1.000}-\frac{1.33324^{2}-1}{1.33324^{2}+2} \times \frac{1}{1.0003} \times \frac{99}{1.000}=0.245$

AP II' :

$n=1.33547, \quad n_{0}=1.33324, \quad d^{17.5} / 4=1.0035, \quad d_{0}^{17.5} / 4=1.0003$

$[n]_{\mathrm{D}}^{17.5}=\frac{1.33547^{2}-1}{1.33547^{2}+2} \times \frac{1}{1.0035} \times \frac{100}{1.000}-\frac{1.33324^{2}-1}{1.33324^{2}+2} \times \frac{1}{1.0003} \times \frac{99}{1.000}=0.264$

In short, the cancerous toxohormone here and the corresponding 


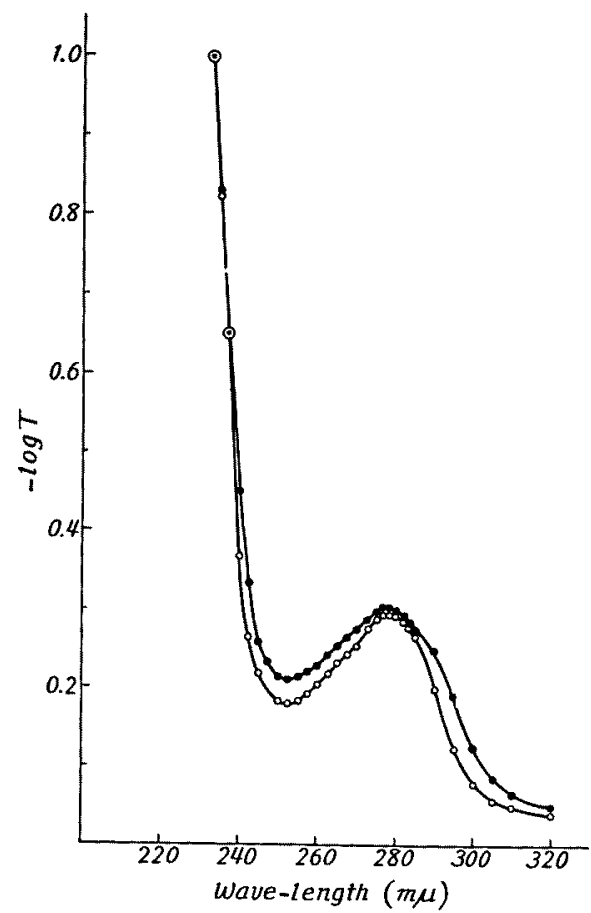

Fig. 5. Ultraviolet absorption spectra of $0.5 \mathrm{mg} \%$ aqueous solutions ( $\mathrm{pH}$ 6.6) of AP II $\left(-\mathrm{O}^{-}-\mathrm{O}^{-}\right)$and of AP II' (-O-O-).

noncancerous differ in composition in serine content, phenylalanine, leucine and isoleucine content as a whole and possibly also in electrophoretic mobility in so far as was examined chemical-analytically and physically.

\section{SUMMARY}

1. There have been isolated toxohormones $\mathrm{AP} \mathrm{II}_{1}$ and $\mathrm{II}^{\prime}$ which are globulins in the cancerous ascitic fluid of stomach cancer patients and noncancerous ascitic fluid of liver cirrhosis patients respectively and both precipitate at 40 to $60 \%$ ethanol and at 1.0-1.4 $\mathrm{M}$ ammonium sulfate.

2. They were examined biologically, chemically and physically.

3. They are devoid of anemia-inducing potency.

4. The former protein is more strongly toxohormone active than the latter, while they differ from each other only regarding serine content and phenylalanine, leucine and isoleucine content as a whole and possibly also regarding electrophoretic mobility, in so far as was examined.

The Ministry of Education gave a grant in aid to us through the Grant Committee for Medical, Dental and Pharmaceutical Researches, which is gratefully acknowledged. H. Masamune. 


\section{References}

1) Masamune, Kaketa \& Abe, S., Tohoku J. Exp. Med., 1958, 67, 329 ; Masamune, Hakomori, Kaketa \& Abe, S., ibid., 1958, 67, 334 ; Masamune, Hakomori, Kaketa, Sinohara \& Abe, S., ibid., 1958, 68, 63.

2) Masamune, Kawasaki, Abe, S., Oyama, \& Yamaguchi, ibid., 1958, 68, 81 ; Kawasaki, ibid., 1958, 68, $119 ; 1959,69,153$.

3) Masamune, Tsuiki, Kamiyama, Abe, S., Haga, Kawasaki, Kaketa \& Abe, Sh., ibid., 1958, 67, 309.

4) Sugimoto, ibid., 1956, 64, 271 ; Masamune, Hakomori, Sugimoto \& Genda, unpublished.

5) Gornall, Bardawill \& David, J. Biol. Chem., 1948, 177, 751.

6) Masamune \& Kawasaki, Tohoku J. Exp. Med., 1956, 63, 369 (f. 372).

7) Masamune \& Yosizawa, ibid., 1953, 59, 1.

8) Masamune \& Sakamoto, ibid., 1956, 63, 345.

9) Masamune \& Yosizawa, ibid., 1957, 65, 169.

10) Masamune \& Kawasaki, ibid., 1956, 63, 369 (f. 381).

11) Werner \& Odin, Acta soc. med. Upsal., 1952, 57, 270.

12) Masamune \& Hakomori, Tohoku J. Exp. Med., 1956, 64, 59. 